\title{
Note on a Filarial Infection in Indian Rock Pigeon
}

\author{
By B. P. PANDE, P. RAI and B. B. BHATIA
}

\section{Introduction}

Miller (1937) reviewed the Helminths found in domestic pigeon giving their distribution, location in the host and pathogenicity and listed, under Filariidae, the two species known from Europe - Eulimdana clava (Wedl, 1855) found in the connective tissue around the trachea and E. mezzantii (Railliet, 1895) in the connective tissue of the neck. The genus Eulimdana, under the sub-family Aproctinae and related to Pelecitus Railliet and Henry, 1910, was established by Founikoff (1934) with Filaria clava Wedl, 1855 as its type species. Under Filariidae, Yamaguti (1935) added his genus Spirofilaria with S. podicipitis n. sp. as the type species which later was considered identical to Spiroptera helix Linstow, 1899 [ $=$ S. fulicae-atrae (Diesing, 1861)] by Baylis (1944) who also believed that Spirofilaria was closely related to Pelecitus. This genus was reported for the first time from South India from the tendons of the toes of a honey-buzzard when Baylis recorded P. falconis (Rud., 1819) $[=P$. serpentulus (Diés.)]. Li (1940), after examining specimens of Filaria clava collected from sub-cutaneous tissue of pigeon, stated that this species closely resembled $P$. helicinus, the type species of Pelecitus.

Skryabin and Shikhobalova (1948), in their illustrated accounts, recognized eleven species under Pelecitus (syn. Eulimdana) giving the synonyms of some of the species including the species found in Columba livia viz. Pelecitus clavus (= Eulimdana clava Founikoff) and P. mezzantii (also reported by Neveu-Lemaire, 1936). Diagrams of female in the case of the former and of posterior end of male in the latter have alone been given in this treatment. Stoican (1953), recording Eulimdana clava (sub-family Aproctinae) for the first time in Rumania, found that the adult Nematodes localized in the peritracheal connective tissue near the tracheal bifurcation were pathogenic. Chabaud and Anderson (1959), in their classification of Filarioids, included Pelecitus (with Spirofilaria and Eulimdana as its synonyms) under the subfamily Dirofilariinae of Onchocercidae. According to Chabaud (1961) Pele- 
citus has, in addition to P. clava (Wedl, 1855) occurring in Europe and P. mezzantii (Railliet, 1895) in Italy as parasites of Columba livia, the nine other species: P. helecinus (Molin, 1860) ; P. calamiformis (Schneider, 1866) $=P$. tercostatus after Travassos, $1930 ; P$. alatus Walton, $1927 ; P$. tercostatus (Molin, 1859) ; P. circularis (Molin, 1859) ; P. quadripapillosus (Molin, 1859) ; $P$. falconis (Rud., 1819) $=P$. serpentulus $($ Diesing) $; P$. armenica Tschertkova, $1946 ;$ P. fulicae-atrae $($ Diesing, 1861$)=P$. helix $($ Linstow, 1899) $=P$. podicipitis Yamaguti, 1935.

\section{Materials}

While collecting the parasites of Blue Rock Pigeon, on some occasions the cervical region was found to harbour in the sub-cuticular connective tissue, in and around the mesentery surrounding the crop, a filarioid Nematode of which both males and females were available for study in living condition, from fixed and cleared specimens and in stained sections of the affected tissue. The specimens belonging to Pelecitus clava, so far known from domestic pigeon, are briefly described with illustrations of the salient features of the morphology. The pathological changes revealed in the tissues of its location are also indicated and the sheathed microfilariae, cut in sections of the skin and in the mesenteric part of the crop, have been studied. Examination of blood in all the birds that harboured the infection proved negative for the microfilariae. Ray and Das Gupta (1936) have, however, recorded from the blood of an Indian pigeon, Columba intermedia (?), an unsheathed microfilaria which they have named as Microfilaria columbae n. sp. This larval form was found to have infiltrated almost every tissue including brain. Adult worms were not found but the authors suggested that the larvae were probably those of Eulimdana clava.

\section{Observations}

Worms, small, thread-like, milky-white, extremities rounded, lips absent. Cephalic papillae one pair lateral and two pairs sub-median (fig. 1). EEsophagus, short, undivided. Cuticle some-what reinforced with longitudinal markings.

Males (2 specimens available), markedly smaller than females, 4,95-5,85 mm. long, maximum breadth $0,14-0,18 \mathrm{~mm}$. Esophagus $0,24 \mathrm{~mm}$. long. Nervering $0,09 \mathrm{~mm}$. distant from anterior end. Caudal alae equal. Testis with initial loop $0,8 \mathrm{~mm}$. distance from the anterior end, anteriorly extending to the œsophageal region and coiling back behind the nerve-ring (fig. 2). Spicules, nearly equal, yellowish, weakly-chitinized, 0,1-0,11 $\mathrm{mm}$. long with proximal end broader and distal end narrower but blunt. Pedunculated 

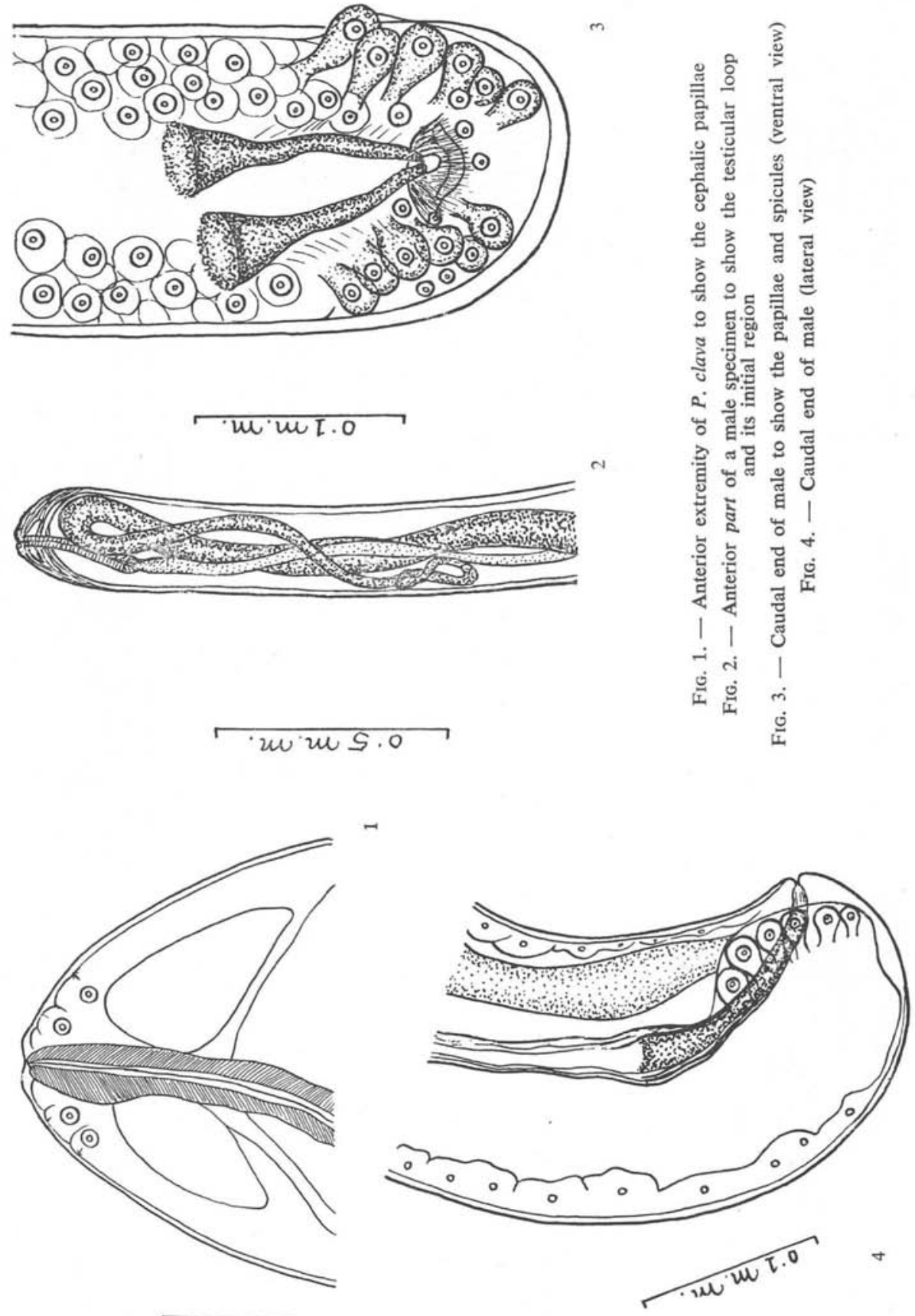

w w t.o 

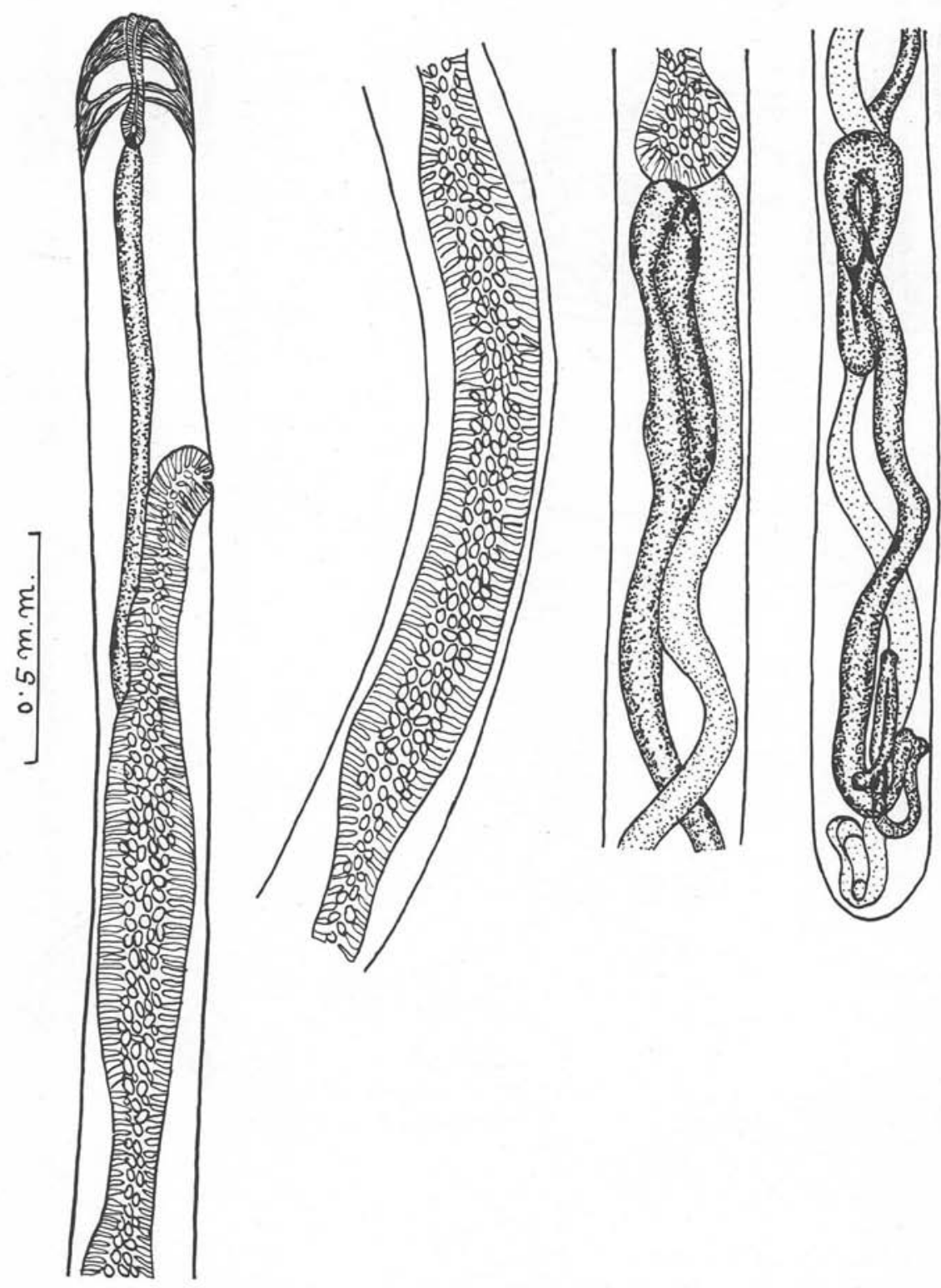

Fig. 5. - Entire female of $P$. clava 


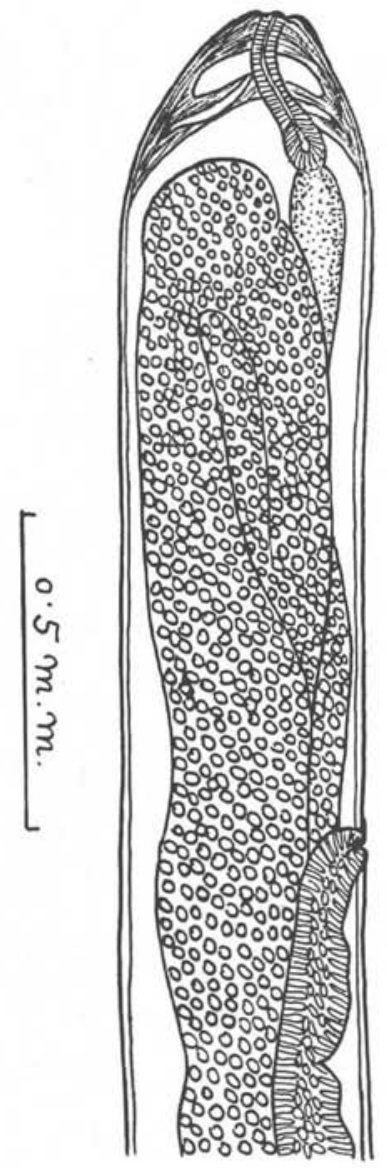

Fig. 6. - Anterior part of a female showing œsophagus, intestine, vulva, portions of vagina and uterus

Fig. 7. - Caudal end of a female (ventral view). Observe distal intestinal region (non-functional) terminating at anus

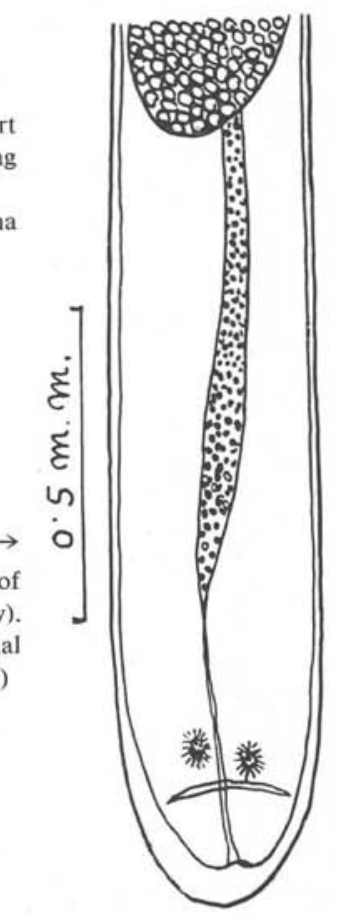

Fig. 8. - Section through œsophagus (oe). Observe the three cephalic papillae on one side

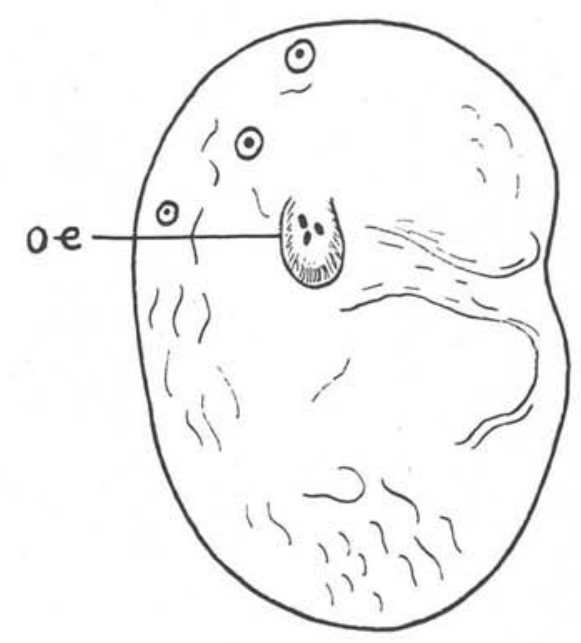



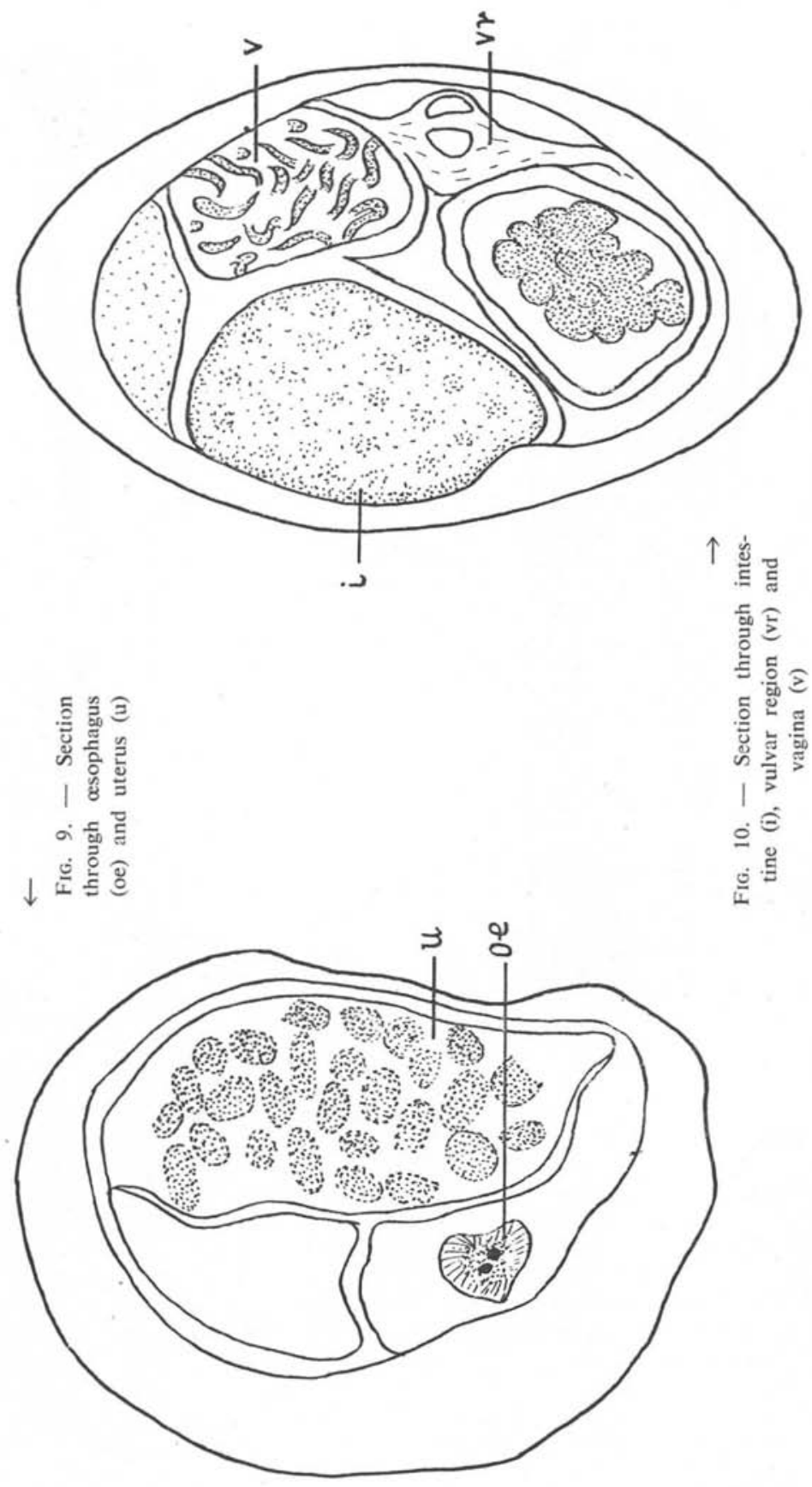

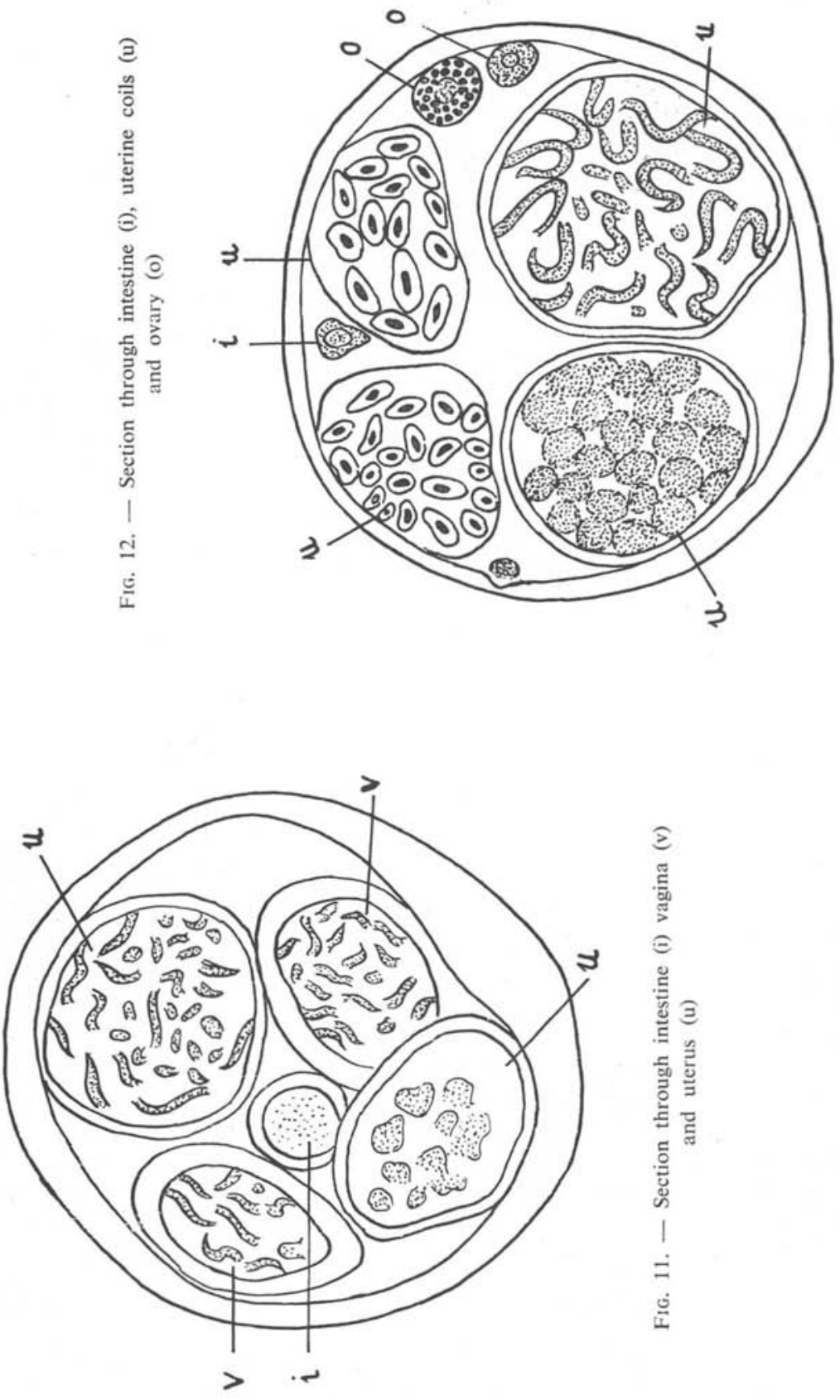


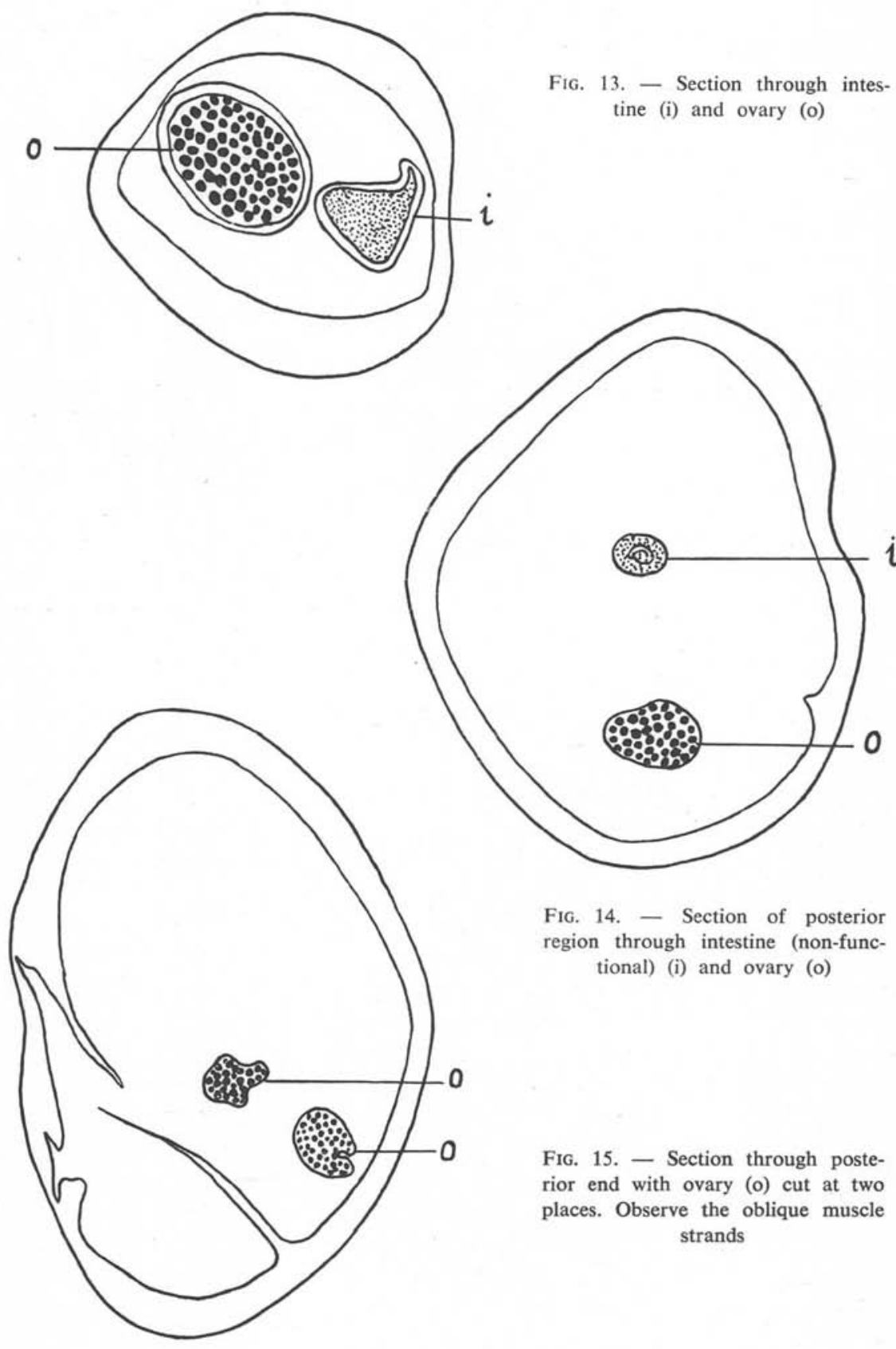


$0.02 \mathrm{~m} \cdot \mathrm{m}$

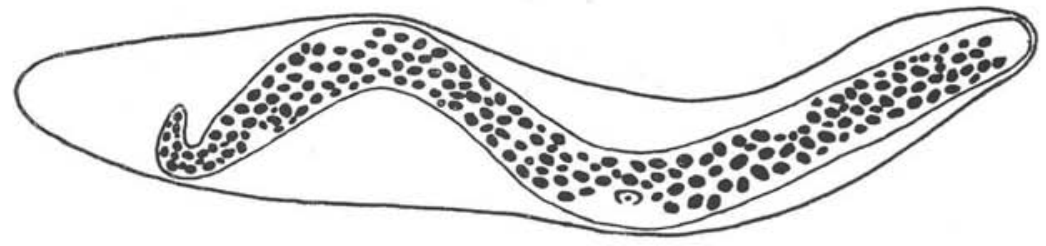

16

$0.02 \mathrm{~m} . \mathrm{m}$

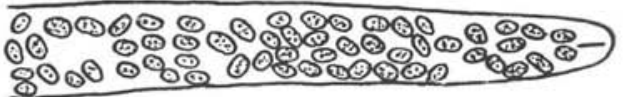

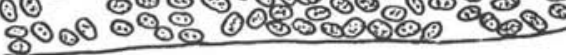

17

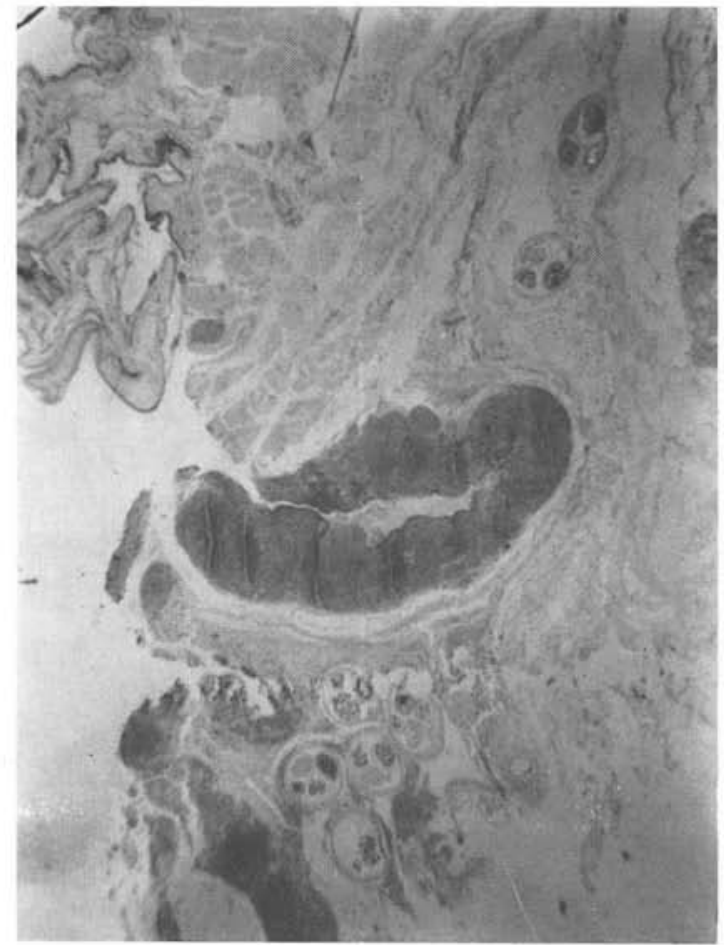

Fig. 16. - Microfilaria with sheath (from a ruptured female)

FIG. 17. - Anterior end of a microfilaria showing papilla/stylet at its anterior extremity (from section)

FIG. 18. - Photomicrograph of a section of skin showing female cut in the haemorrhagic zone 


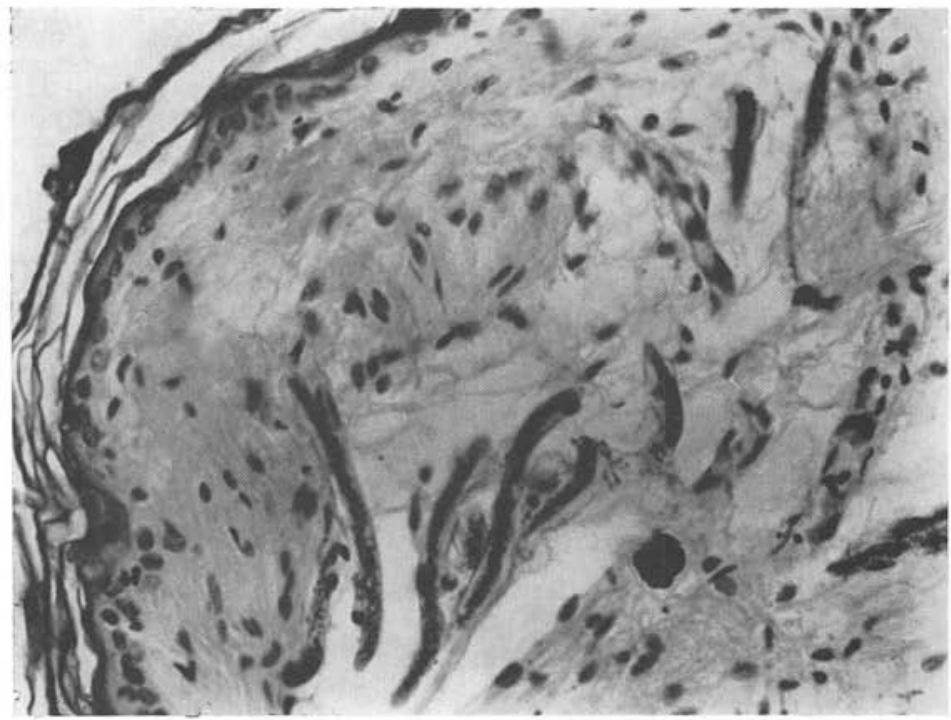

FIG. 19. - Photomicrograph of a section of skin showing microfilariae reaching upto epidermis

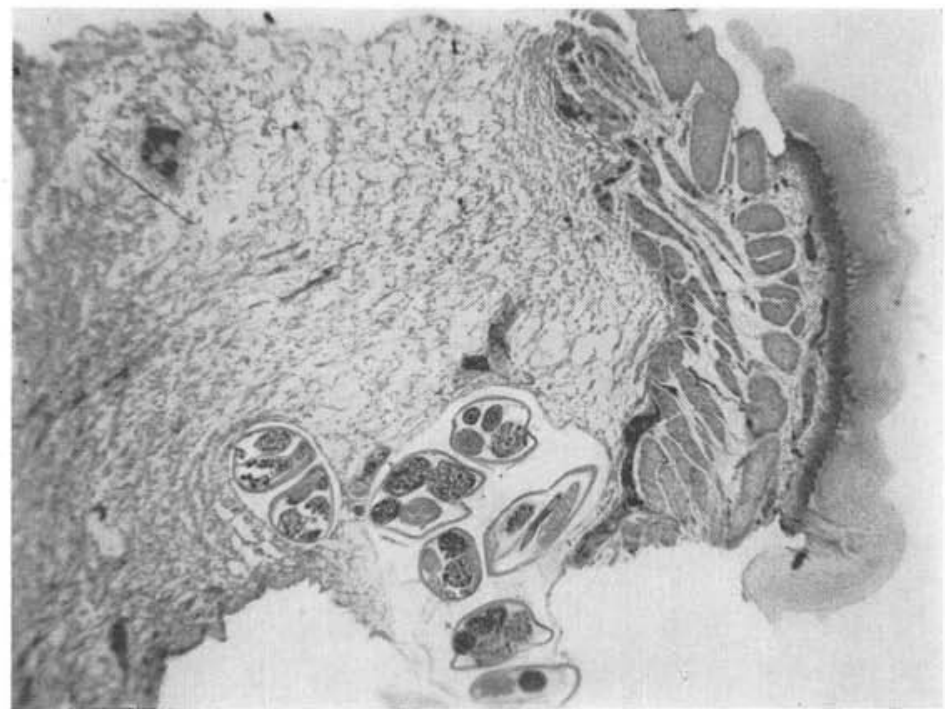

FIG. 20. - Photomicrograph of a section of crop showing worm reaching the muscular layer 
papillae consisting of three pairs of pre-anals, one of adanal and two of postanals (fig. 3 and 4). Anus 0,36-0,49 $\mathrm{mm}$. distant from the posterior tip.

Females ( 9 specimens studied), 8-21 mm. long, 0,21-0,37 mm. in maximum breadth. Esophagus 0,25-0,33 mm. long (fig. 6 and 8). Intestine, nearly straight, with lumen narrow in regions of vagina and uterine coils, posteriorly narrowing as thin thread particularly near the tail (fig. 6 and 14). Nerve-ring 0,1-0,16 mm. distant from the anterior end. Genital pore 0,8-2 mm. distant from the anterior end (fig. 6 and 10). Vagina, muscular, strongly developed, passing posteriorly to receive the two distal uterine limbs lying parallel (fig. 5 and 11). [Youngest specimen has vagina $3,6 \mathrm{~mm}$. long. In all gravid forms, the vagina, full of microfilariae (fig. 11), lies obscured by the winding uterine coils which, in the pre-vulvar region, extend beyond the posterior border of the œsophagus (fig. 6 and 9). The uterine loops are packed up with microfilariae and segmented eggs with thin shells (fig. 12). The ovaries have the initial coils in posterior most region (fig. 13, 14 and 15)]. Tail 0,03-0,04 mm. long. Sheathed microfilariae, recovered from ruptured specimens, 0,7$0,87 \mathrm{~mm}$. long and 0,04-0,065 mm. maximum breadth (fig. 16), those measured from sections being $0,73-0,8 \mathrm{~mm}$. long and $0,04-0,065 \mathrm{~mm}$. in breadth and exhibiting at the anterior end a papilla/stylet (fig. 17).

A large number of worms were detected in the areolar connective tissue over the cervical muscles and the infection, on one occasion, was heavy when worms lay in a haemorrhagic clot of blood found just below the skin of the neck at the site indicated by Stoican (fig. 18). The stained serial sections of the affected skin and the crop show the worms cut below the muscular layers and in the wall of the crop exhibit the tunnelling activity of the gravid females with a number of sheathed microfilariae also cut in the vicinity of worms, both in the sections of skin and crop. Microfilarial distribution, studied in these sections of the skin, revealed the larvae not only at the sites the worms lay but in the intermuscular connective tissue and in the dermis with some having reached even the epidermis (fig. 19). A marked congestion of blood vessels, some amount of haemorrhage and lymphocytic infiltration were observed at the places the worms occurred in the skin. The sections of the crop revealed its lining destroyed by worms that had reached as deep as the muscular coat (fig. 20). Some degree of congestion, cellular infiltration with lymphocytes and a few eosinophiles were in evidence.

\section{Remarks}

The genus Pelecitus, according to Yorke and Maplestone (1926), has in males 2-4 pairs of pre-anal papillae (which are sometimes absent), a variable number of post-anal papillae and equal and sub-equal spicules which are very short and delicate. The females, with one or two pairs of pedunculated 
papillae and vulva near the anterior extremity, are oviparous. Baylis believed that in Pelecitus the caudal alae and papillae were almost, if not quite, symmetrical. The six species listed under it by Yorke and Maplestone had excluded all those that now come under it. Accordingly, some of its original characterisation would no longer be fully applicable. The present material with body dimensions somewhat smaller than those recorded by Stoican who gives the pairs of caudal papillae as 3 pre-anals and 3 post-anals has been identified as belonging to $P$. clava. The position of the vulva behind the csophagus is in accordance with the diagram given by Skryabin and Shikhobalova which, however, shows the vulva in continuity of the ascending uterine limb and without a clear representation of the vagina. The tail region of the female shows the anal opening which, in our material, appears as non-functional. The pathological picture of the skin in the affected cervical region appears to resemble that indicated by Stoican but the invasion by the parasite of the crop is evidently a first record.

\section{Summary}

The occurrence of $P$. clava, so far recorded from Europe, China and U.R.S.S., is reported from Indian Rock Pigeon and a brief account of its morphology, location and pathogenic effects both in the skin and crop, has been attempted.

\section{Résumé}

La présence de Pelecitus clava (Dirofilariinae - Onchocercidae), signalée jusqu'alors en Europe, en Chine et en U.R.S.S., est observée pour la première fois aux Indes, chez des Pigeons sauvages (Blue Rock pigeons).

Une brève description des vers adultes est donnée, ainsi qu'une étude sur leur localisation au niveau de la peau ou du jabot, et sur leur rôle pathogène.

\section{Acknowledgement}

Thanks are due to Prof. Alain-G. Chabaud for his suggestions and to the Principal of the College for facilities provided.

\section{Références}

Baylis (H. A.), 1944. - Notes on some Parasitic Nematodes. Ann. Mag. Nat. Hist., Sér. 11, 11, 793-804.

Chabaud (A.-G.), 1961. - Personal communication. 
Chabaud (A.-G.) and Anderson (R.-C.), 1959. - Nouvel essai de classification des Filaires (superfamille des Filarioidea). II. Ann. de Parasit. Hum. et Comp., 34, 64-87.

FouniKofF (S.), 1934. - Situation de Filaria clava Wedl, 1855 des Pigeons dans la classification des Nématodes. Ibid., 12, 61-66.

L. (S. Y.), 1940. - On Filaria clava Wedl, 1855, parasite of the subcutaneous tissue of pigeon. Chinese Med. J., Suppl., 3, 295-299.

Miller (M. J.), 1937. - The parasites of pigeons in Canada. Cand. J. Res., D 15, 91-103.

Neveu-Lemaire, 1936. - Traité d'Helminthologie médicale et vétérinaire, Paris, 23, 1.514 pp.

RAY (H.-N.) and Das Gupta (M.), 1936. - Microfilaria columbae n. sp. du sang d'un Pigeon indien: Columba intermedia. Ann. Parasitol., Paris, 15, 256260.

Skryabin (K. I.) and Shikhobalova (N. P.), 1948. - Filariae of animals and man, for veterinarians medical men and biologists, Moscow: Ogiz-Selkhozgig, 608 pp. (in Russian).

Storcan (E.), 1953. - \&ulimdana clava $\gg$ la porumbel in R.P.R. Anuarul Institutuli de Patologie si Igiena Animala. Bucharest, 4, 304-307.

Yamaguti (S.), 1935. - Studies on the Helminth fauna of Japan. Part. 12. Avian Nématodes, I. Jap. J. Zool., 4, 403-431.

Yorke (W.) and Maplestone (P. A.), 1926. - The Nematode Parasites of Vertebrates. J. et A. Churchill, London, 536 pp.

Department of Parasitology, U.P. College of Veterinary Science and Animal Husbandry, Mathura (India) 